Article

\title{
Farming Practices for Reducing Ammonia Emissions in Polish Agriculture
}

\author{
Arkadiusz Piwowar (D) \\ Faculty of Economics and Finance, Wroclaw University of Economics and Business, Komandorska Street 118/120, \\ 53-345 Wrocław, Poland; arkadiusz.piwowar@ue.wroc.pl; Tel.: +48-713-680-430
}

Received: 16 November 2020; Accepted: 11 December 2020; Published: 13 December 2020

\begin{abstract}
The main source of ammonia emissions in Poland is agriculture. In 2017, approximately $94 \%$ of the total ammonia emissions in Poland came from agriculture, of which the largest part $(78 \%)$ was related to livestock manure and $22 \%$ to nitrogen fertilization. This study presents the results of representative research on the implementation of technologies and techniques that reduce ammonia emissions on farms in Poland. The research methodology, including statistical data analysis (multiple correspondence analysis), allowed comparisons to be made of the applied low-carbon practices, taking into account farmers' characteristics (e.g., age and education) and farm attributes (area size, location, etc.). According to the research, both in the case of mineral fertilization and animal production, farmers in Poland relatively rarely undertake pro-ecological practices aimed at reducing ammonia emissions. The most frequently undertaken activities include dividing the doses of nitrogen fertilizers (in terms of plant production) and the use of feed additives (in terms of livestock production). Empirical studies, supported by correspondence analyses, confirmed a significant differentiation of coexistence and strength of the relationship between the studied variables. The use of correspondence analysis made it possible to precisely recognize the differentiation and co-occurrence of variable categories. In the course of analytical work, a relatively strong correlation was found between the use of divided doses of nitrogen fertilizers and the economic size of farms $\left(\varphi^{2}=0.11571\right)$. In turn, the use of feed additives was most strongly determined by the economic size of farms $\left(\varphi^{2}=0.072614\right)$ and the location of farms $\left(\varphi^{2}=0.072223\right)$.
\end{abstract}

Keywords: emissions of ammonia; multiple correspondence analysis (MPA); agriculture and rural areas; rural producers' behavior

\section{Introduction}

Agriculture faces many difficult challenges in the field of environmental protection, which require technological changes both in agriculture itself and in its surroundings (including agrochemicals companies). The intensification of agricultural production, which was aimed at increasing food supply and ensuring a high level of physical and economic food security globally, has consequences in the form of negative externalities (having a direct and indirect impact on water quality and availability, air quality, soil quality, biodiversity, animal health and welfare, etc.). The industrialization of agriculture is associated with the need to bear the effects of anthropogenic activities. One of the main challenges is to reduce ammonia emissions, which contribute to eutrophication, acidification, and loss of biodiversity not only in rural areas [1,2]. Ammonia was included as an air pollutant in the Gothenburg Protocol [3]. Harmfulness of ammonia results not only from its direct toxicity, but primarily from the reactions it enters in the water and soil environment (volatilization from livestock manures and mineral fertilizer application). It is emphasized in the literature that it is agricultural activity that contributes to around $80-90 \%$ of the total anthropogenic $\mathrm{NH}_{3}$ emission [4]. Global agricultural $\mathrm{NH}_{3}$ emissions increased by $90 \%$ between 1970 and 2005 [5]. The harmful effects of ammonia on humans are mainly related to 
the deterioration of respiratory function and disorders of the eye [6,7]. Ammonia emissions strongly contribute to fine particulate matter (PM2.5-particles with a diameter of 2.5 micrometers or less) pollution and are associated with premature human mortality [8-10]. The literature on the subject also emphasizes the role of non-agricultural sources of ammonia emissions (wild animals and sea bird colonies, industry, etc.) [11-13]. Nevertheless, it is the reduction of ammonia emissions from agriculture that is the primary element in the context of improving air and water quality and the sustainable development of agriculture and rural areas. Reducing $\mathrm{NH}_{3}$ emissions is one of the most difficult challenges for environmental regulators around the world [14].

The issue of ammonia emissions from agricultural sources concerns many regions. The literature on the subject analyses emissions, among others, in North and South America, Asia, and Australia [15-22]. The greatest interest includes areas with a large livestock population, high consumption of nitrogen fertilizers, and thus high $\mathrm{NH}_{3}$ emission. As Xu et al. [23] indicate, excessive ammonia $\left(\mathrm{NH}_{3}\right)$ emitted from nitrogen $(\mathrm{N})$ fertilizer applications plays an important role in atmospheric aerosol production, resulting in visibility reduction and regional haze. Emissions generally reach their highest levels twice a year-in spring and autumn [20,24]. Research on ammonia emissions is also carried out in the European Union. The main source of anthropogenic $\mathrm{NH}_{3}$ in Europe is animal husbandry. Both United Nations treaties and European Union legislation are increasingly limiting atmospheric ammonia emissions [25]. The Convention on Long-Range Transboundary Air Pollution (CLRTP) and the European Union National Emission Ceilings Directive (NECD) set limits for national $\mathrm{NH}_{3}$ emissions and require the reporting of annual emission inventories to demonstrate compliance [5]. Among European countries, Germany, France, Spain, Italy, and Poland have the highest levels of ammonia emissions from agricultural sources (Table 1).

Table 1. Agricultural ammonia emissions in the EU-28 in 2013-2017 [26].

\begin{tabular}{|c|c|c|c|c|c|c|c|c|c|c|}
\hline \multirow{2}{*}{ Specification } & \multicolumn{2}{|c|}{2013} & \multicolumn{2}{|c|}{2014} & \multicolumn{2}{|c|}{2015} & \multicolumn{2}{|c|}{2016} & \multicolumn{2}{|c|}{2017} \\
\hline & Tonne & $\%$ & Tonne & $\%$ & Tonne & $\%$ & Tonne & $\%$ & Tonne & $\%$ \\
\hline Belgium & 66,048 & 1.88 & 64,423 & 1.81 & 63,994 & 1.78 & 63,013 & 1.74 & 62,323 & 1.71 \\
\hline Bulgaria & 37,927 & 1.08 & 41,274 & 1.16 & 41,932 & 1.16 & 42,732 & 1.18 & 41,533 & 1.14 \\
\hline Czechia & 64,770 & 1.84 & 65,227 & 1.83 & 65,914 & 1.83 & 65,474 & 1.81 & 60,656 & 1.67 \\
\hline Denmark & 69,831 & 1.99 & 70,519 & 1.98 & 70,578 & 1.96 & 70,852 & 1.96 & 72,216 & 1.99 \\
\hline Germany & 641,553 & 18.25 & 644,822 & 18.12 & 655,750 & 18.20 & 647,625 & 17.88 & 639,807 & 17.60 \\
\hline Estonia & 9306 & 0.26 & 9483 & 0.27 & 8987 & 0.25 & 8888 & 0.25 & 8998 & 0.25 \\
\hline Ireland & 106,342 & 3.03 & 106,912 & 3.00 & 109,408 & 3.04 & 114,931 & 3.17 & 117,382 & 3.23 \\
\hline Greece & 56,671 & 1.61 & 54,668 & 1.54 & 52,163 & 1.45 & 51,392 & 1.42 & 50,130 & 1.38 \\
\hline Spain & 410,882 & 11.69 & 431,792 & 12.14 & 442,427 & 12.28 & 453,398 & 12.51 & 469,857 & 12.92 \\
\hline France & 555,502 & 15.80 & 565,784 & 15.90 & 571,392 & 15.86 & 569,858 & 15.73 & 568,243 & 15.63 \\
\hline Croatia & 30,205 & 0.86 & 28,986 & 0.81 & 32,805 & 0.91 & 31,441 & 0.87 & 31,827 & 0.88 \\
\hline Italy & 363,456 & 10.34 & 354,128 & 9.95 & 355,409 & 9.87 & 370,022 & 10.21 & 362,178 & 9.96 \\
\hline Cyprus & 6035 & 0.17 & 5936 & 0.17 & 5986 & 0.17 & 6174 & 0.17 & 6272 & 0.17 \\
\hline Latvia & 13,638 & 0.39 & 13,981 & 0.39 & 14,028 & 0.39 & 13,973 & 0.39 & 14,039 & 0.39 \\
\hline Lithuania & 26,772 & 0.76 & 27,159 & 0.76 & 27,134 & 0.75 & 26,354 & 0.73 & 25,871 & 0.71 \\
\hline Luxembourg & 5068 & 0.14 & 5173 & 0.15 & 5254 & 0.15 & 5376 & 0.15 & 5445 & 0.15 \\
\hline Hungary & 72,791 & 2.07 & 73,977 & 2.08 & 78,256 & 2.17 & 78,438 & 2.17 & 79,622 & 2.19 \\
\hline Malta & 1173 & 0.03 & 1161 & 0.03 & 1152 & 0.03 & 1099 & 0.03 & 1065 & 0.03 \\
\hline Netherlands & 105,530 & 3.00 & 109,960 & 3.09 & 111,100 & 3.08 & 109,720 & 3.03 & 113,834 & 3.13 \\
\hline Austria & 61,398 & 1.75 & 62,299 & 1.75 & 62,945 & 1.75 & 63,874 & 1.76 & 64,615 & 1.78 \\
\hline Poland & 274,266 & 7,80 & 270,052 & 7.59 & 266,270 & 7.39 & 272,841 & 7.53 & 287,914 & 7.92 \\
\hline Portugal & 42,752 & 1.22 & 45,150 & 1.27 & 46,257 & 1.28 & 46,691 & 1.29 & 47,060 & 1.29 \\
\hline Romania & 150,223 & 4.27 & 147,225 & 4.14 & 150,781 & 4.19 & 147,135 & 4.06 & 144,309 & 3.97 \\
\hline Slovenia & 16,480 & 0.47 & 16,789 & 0.47 & 16,900 & 0.47 & 17,190 & 0.47 & 16,893 & 0.46 \\
\hline Slovakia & 28,982 & 0.82 & 29,964 & 0.84 & 29,709 & 0.82 & 25,003 & 0.69 & 24,044 & 0.66 \\
\hline Finland & 29,911 & 0.85 & 30,214 & 0.85 & 28,863 & 0.80 & 28,532 & 0.79 & 27,795 & 0.76 \\
\hline Sweden & 47,521 & 1.35 & 47,783 & 1.34 & 47,873 & 1.33 & 46,803 & 1.29 & 46,999 & 1.29 \\
\hline United Kingdom & 219,710 & 6.25 & 233,235 & 6.56 & 238,996 & 6.63 & 244,037 & 6.74 & 244,928 & 6.74 \\
\hline EU (28) & $3,514,740$ & 100 & $3,558,074$ & 100 & $3,602,262$ & 100 & $3,622,865$ & 100 & $3,635,852$ & 100 \\
\hline
\end{tabular}


The subject of this paper concerns the scale of implementation of low-emission technologies and techniques in agricultural activity in Poland, which may contribute to the reduction of ammonia emissions from agricultural sources. In Poland, ammonia emission from agricultural sources amounted to 287,914 tonnes in 2017, which accounted for $7.9 \%$ of emissions in the European Union (EU-28). Agriculture in Poland, especially animal production, is a significant source of gaseous pollution. Poland is one of the leading poultry producers in Europe $[27,28]$. Moreover, Poland has one of the highest levels of mineral fertilizer consumption in Europe (and more than half in the structure of their consumption is nitrogen). The large fragmentation of farms in Poland against the background of other countries in the European Union, with a large diversity of conditions and the scale of agricultural management in spatial terms, indicates potentially interesting cognitive conclusions in the studied subject. Polish agriculture is obliged to reduce ammonia $\left(\mathrm{NH}_{3}\right)$ emissions, compared to 2005 , by $1 \%$ annually in 2020-2029 and by $17 \%$ annually from 2030 [29].

In the literature on the subject, there is little detailed research on agricultural practices in the studied area. As Insausti et al. [14] emphasize, the current priority is to improve agricultural practices to reduce ammonia emissions. The main purpose of the paper was to analyze and assess the behavior of farmers in Poland in relation to low-emission practices that limit ammonia emissions from animal and plant production. This study contains the application of correspondence analysis to study the behavior of farmers in the field of low-emission agricultural practices, based on the results of the author's own research (survey research among farmers). The use of data from public statistics and analysis of correspondence on empirical material allowed for an in-depth analysis of farmers' behavior in the context of ammonia emissions in Polish agriculture. The results of the analyses are of application significance, providing all interested parties (scientists, agricultural advisors, etc.) with broad information on the importance and practical possibilities of actions (implemented and not implemented) limiting the formation of ammonia in the course of agricultural activity. Agriculture, among all sectors of the economy, is the main source of ammonia emission in Poland. Ammonia, transformed in chemical and photochemical processes into atmospheric aerosols, contributes to the formation of aerosols that are part of the fine dust [30,31]. Accordingly, the increase in $\mathrm{NH}_{3}$ emissions has a negative impact on public health and the environment, including climate change. It is worth noting that among the European Union countries, it is Poland where the issue of air pollution by suspended dust is severely felt and repeatedly emphasized in the literature on the subject $[32,33]$. Poland should take intensive, urgent measures to achieve the necessary air quality standards in this regard [34].

This study consists of several separate fragments. The next part presents information on the research methodology (scope and type of data, research procedure, and research area), followed by characterization of the size and sources of ammonia emissions in Poland, with particular emphasis on the agricultural sphere. The next part of the work presents the results of a multiple correspondence analysis, a discussion with an indication of a wider context and a summary.

\section{Materials and Methods}

\subsection{Area of Research}

The aim of the paper was devoted to a review of Polish and foreign literature, as well as own experience resulting from the implementation of nationwide surveys. The article uses both secondary and primary data. Ammonia emission volumes and sources were taken from reports prepared by the National Centre for Emissions Balancing and Management (KOBIZE). The time scope of the analyses covered the years 2013-2017. The primary data necessary for analyzing the behavior of farmers in the subject matter were the results of surveys carried out in Poland in November 2017 to March 2018. The general purpose of the survey was to collect empirical material useful for solving the identified research problems within the theme-low-emission agriculture in Poland $[35,36]$. The research was financed by the National Science Centre in Poland under the awarded grant. 1101 farmers took part in 
the research using the multi-stage random selection method. The following random drawing scheme was used. The research was carried out in all six macro-regions in Poland (NUTS 1), in which one voivodship was drawn, and then in each voivodship three districts were drawn where survey research was conducted. Therefore, a random selection of elements at subsequent levels was carried out. This method was optimal because the population is characterized by very large geographical dispersion and a significant number of farms (in 2017 there were 1.4 million farms in Poland). The spatial scope of surveys is shown in Figure 1.

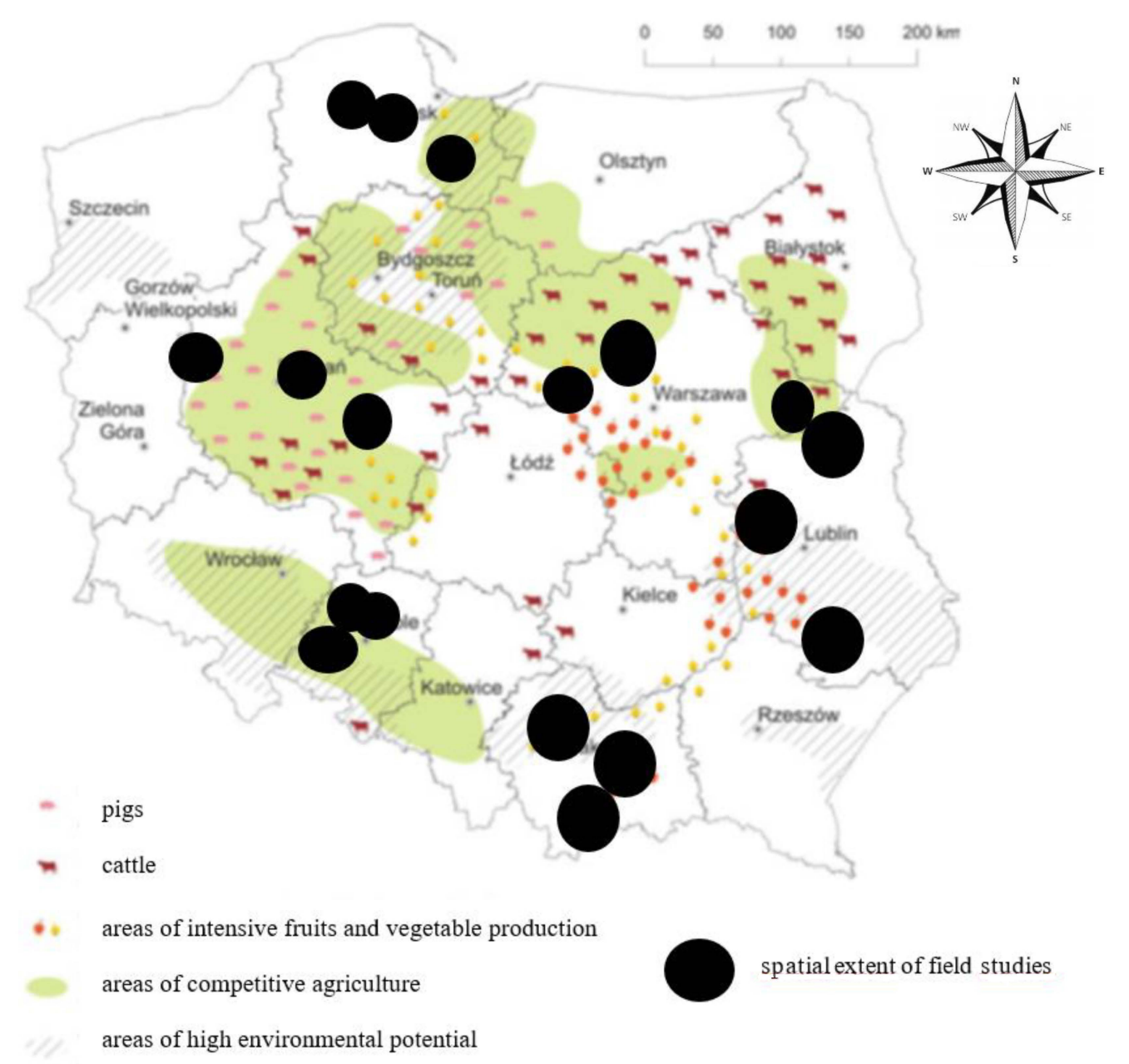

Figure 1. Main food producing areas in Poland and spatial extent of field studies [37].

The area of the agricultural holdings surveyed was $31,819.75$ ha of agricultural lands, while the average area of an agricultural holding surveyed was 28.90 ha of agricultural lands.

\subsection{Background Characteristics of Respondents}

Table 2. presents the percent distribution of the interview.

Precise determination of the objectives, geographical, temporal, subject, and object scope of the conducted research, as well as the principles of selection of respondents and the size of the sample justify the conclusion that the applied representative procedural sample has a composition similar to the composition of the population due to any features. Due to the fact that some of the questionnaires did not contain complete answers, reduction methods were applied, and 1034 questionnaires (in the field of plant production) and 520 questionnaires (in the field of livestock production) were allowed for further analysis. 
Table 2. General characteristics of the test sample.

\begin{tabular}{|c|c|c|}
\hline \multirow{2}{*}{ Specification } & Population & Share in the Test Sample \\
\hline & (pcs) & $(\%)$ \\
\hline \multicolumn{3}{|c|}{ Age of respondents } \\
\hline $18-29 y$ & 128 & 11.6 \\
\hline $30-39 y$ & 250 & 22.7 \\
\hline $40-49 y$ & 328 & 29.8 \\
\hline $50-59 y$ & 281 & 25.5 \\
\hline$>60 y$ & 102 & 9.3 \\
\hline No data & 5212 & 1.1 \\
\hline Total & 1101 & 100 \\
\hline \multicolumn{3}{|c|}{ Gender of respondents } \\
\hline Women & 197 & 17.9 \\
\hline Men & 901 & 81.8 \\
\hline No data & 3 & 0.3 \\
\hline Total & 1101 & 100 \\
\hline \multicolumn{3}{|c|}{ Education level of respondents } \\
\hline Primary & 44 & 4.0 \\
\hline Graduate vocational school & 389 & 35.3 \\
\hline Secondary & 518 & 47.0 \\
\hline Higher & 142 & 12.9 \\
\hline No data & 8 & 0.7 \\
\hline Total & 1101 & 100 \\
\hline \multicolumn{3}{|c|}{ Number of years worked in agricultural holding } \\
\hline $1-5 y$ & 90 & 8.2 \\
\hline $6-10 y$ & 146 & 13.3 \\
\hline $11-15 y$ & 119 & 10.8 \\
\hline $16-20 y$ & 172 & 15.6 \\
\hline $21-25 y$ & 138 & 12.5 \\
\hline $26-30 y$ & 152 & 13.8 \\
\hline$>31 \mathrm{y}$ & 282 & 25.6 \\
\hline No data & 2 & 0.2 \\
\hline Total & 1101 & 100 \\
\hline \multicolumn{3}{|c|}{ Selected features of agricultural holdings } \\
\hline \multicolumn{3}{|c|}{ Area of agricultural lands [ha] } \\
\hline$<5$ & 88 & 8.0 \\
\hline $5-9.99$ & 195 & 17.7 \\
\hline $10-14.99$ & 191 & 17.3 \\
\hline 15-19.99 & 136 & 12.4 \\
\hline $20-29.99$ & 164 & 14.9 \\
\hline $30-49.99$ & 170 & 15.4 \\
\hline 50-99.99 & 115 & 10.4 \\
\hline$>100$ & 41 & 3.7 \\
\hline No data & 1 & 0.1 \\
\hline Total & 1101 & 100 \\
\hline \multicolumn{3}{|c|}{$\begin{array}{l}\text { Economic size of agricultural holding } \\
\qquad(\mathrm{SO})\end{array}$} \\
\hline$<10$ thousand euro & 316 & 28.7 \\
\hline $10.1-13$ thousand euro & 156 & 14.2 \\
\hline 13.1-20 thousand euro & 188 & 17.1 \\
\hline 20.1-50 thousand euro & 232 & 21.1 \\
\hline $50.1-100$ thousand euro & 99 & 9.0 \\
\hline 100.1-200 thousand euro & 40 & 3.6 \\
\hline$>200$ thousand euro & 4 & 0.4 \\
\hline No data & 66 & 6.0 \\
\hline Total & 1101 & 100 \\
\hline
\end{tabular}




\subsection{Research Methods and Tools}

The survey questionnaire used in the study described above provided information on farmers' production behavior in the area of implementation (or lack of implementation) of low-carbon practices that limit ammonia emissions. For this purpose, the respondents were asked questions about these practices in the field of plant and animal production (Table 3).

Table 3. Questions in the survey regarding low-carbon farming practices in the area of ammonia.

\begin{tabular}{ll}
\hline \multicolumn{1}{c}{ Plant Production } & \multicolumn{1}{c}{ Animal Production } \\
\hline I have a current nitrogen balance & I use nitrogen-fixing preparations in animal nutrition \\
& I limit ammonia emissions by using in livestock buildings: \\
& (a) ultraviolet radiation
\end{tabular}

As mentioned earlier, the questionnaire contained more questions as it was the basis for the implementation of the research project. The questionnaire was divided into 4 thematic blocks (general information about the respondent and their farm-18 questions; crop production -7 questions, animal production -4 questions, ecological activity and awareness-10 questions). The research addressed the issues of renewable energy sources, considerations on the assessment of the ecological awareness of farmers in Poland, etc. This article describes a fragment of research on ammonia emissions from agricultural sources.

The analytical processes used multiple correspondence analysis (MCA) a method of metric multidimensional scaling with a distance of $\chi^{2}$ as a measure of dissimilarity. MCA is a nonlinear multivariate analysis method that integrates ideas from multidimensional scaling [38]. The leading element deciding on the choice of the method was the willingness to understand the structure of the multidimensional data set and the discovery of key, co-occurring groups of categories in the area of applied practices and the characteristics of respondents (personal and attributes of their farms). In the literature on the subject, this method has been used many times to analyze the behavior of farmers, adaptation of new solutions in agribusiness in the context of environmental variables [39-42].

\section{Ammonia Emission in Poland-Size, Sources, Structure, and Options for Improving the Situation}

Poland, like other European countries, is obliged to submit a report and draw up a balance regarding greenhouse gas emissions and removals. As the data from these reports indicate, in Poland animal production contributes the most to the emission of ammonia, and this compound escapes from livestock buildings during the spreading of manure and storage on manure slabs. The optimal management of liquid manure is also a big problem (Table 4).

In Poland, agriculture is the main source of ammonia emissions, and its volume increased in 2013-2017. The main source of emissions is animal production and (to a lesser extent) the use of fertilizers. Specific losses result from the used animal production system, improper storage of feces or errors made during fertilization of fields with organic fertilizer. Moreover, the use of mineral fertilizers (nitrogen losses due to improper fertilization, e.g., pre-sowing and without soil coverage) may contribute to these emissions. Detailed analyses show significant spatial diversity of ammonia emissions from animal production in Poland. This is related to the varied volume of animal production (areas of intensive cattle, pigs, and poultry farming) and productivity. 
Table 4. The volume of ammonia emissions and the place of origin of these emissions from agricultural sources in Poland in 2013 and 2017 [43].

\begin{tabular}{|c|c|c|c|c|}
\hline \multirow{3}{*}{$\begin{array}{l}\text { NFR* Aggregation for } \\
\text { Gridding and LPS (GNFR) }\end{array}$} & \multirow{2}{*}{\multicolumn{2}{|c|}{ NFR * Sectors to Be Reported }} & 2013 & 2017 \\
\hline & & & \multicolumn{2}{|c|}{ Volume } \\
\hline & NFR * Code & Longname & \multicolumn{2}{|c|}{ (kt) } \\
\hline K_AgriLivestock & 3B1a & Manure management-Dairy cattle & 33.58 & 34.44 \\
\hline K_AgriLivestock & $3 \mathrm{~B} 1 \mathrm{~b}$ & Manure management-Non-dairy cattle & 19.01 & 21.69 \\
\hline K_AgriLivestock & 3B2 & Manure management—Sheep & 0.21 & 0.27 \\
\hline K_AgriLivestock & 3В3 & Manure management-Swine & 29.96 & 29.77 \\
\hline K_AgriLivestock & 3B4a & Manure management-Buffalo & $\mathrm{NO}$ & $\mathrm{NO}$ \\
\hline K_AgriLivestock & 3B4d & Manure management-Goats & 0.07 & 0.04 \\
\hline K_AgriLivestock & 3B4e & Manure management-Horses & 0.74 & 0.67 \\
\hline K_AgriLivestock & 3B4f & Manure management-Mules and asses & $\mathrm{NO}$ & $\mathrm{NO}$ \\
\hline K_AgriLivestock & 3B4gi & Manure management_-Laying hens & 6.54 & 6.56 \\
\hline K_AgriLivestock & 3B4gii & Manure management-Broilers & 3.91 & 6.76 \\
\hline K_AgriLivestock & 3B4giii & Manure management-Turkeys & IE & IE \\
\hline K_AgriLivestock & 3B4giv & Manure management-Other poultry & 6.80 & 7.87 \\
\hline K_AgriLivestock & 3B4h & $\begin{array}{l}\text { Manure management-Other animals (please } \\
\text { specify in IIR) }\end{array}$ & 0.01 & 0.02 \\
\hline L_AgriOther & 3Da1 & $\begin{array}{c}\text { Inorganic N-fertilizers (includes also urea } \\
\text { application) }\end{array}$ & 63.42 & 61.89 \\
\hline L_AgriOther & 3Da2a & Animal manure applied to soils & 103.24 & 111.15 \\
\hline L_AgriOther & $3 \mathrm{Da} 2 \mathrm{~b}$ & Sewage sludge applied to soils & 0.57 & 0.52 \\
\hline L_AgriOther & $3 \mathrm{Da} 2 \mathrm{c}$ & $\begin{array}{l}\text { Other organic fertilizers applied to soils } \\
\text { (including compost) }\end{array}$ & $\mathrm{NE}$ & NE \\
\hline L_AgriOther & $3 \mathrm{Da} 3$ & Urine and dung deposited by grazing animals & 6.19 & 6.26 \\
\hline L_AgriOther & 3Da4 & Crop residues applied to soils & $\mathrm{NE}$ & NE \\
\hline L_AgriOther & $3 \mathrm{Db}$ & Indirect emissions from managed soils & $\mathrm{NE}$ & NE \\
\hline L_AgriOther & 3Dc & $\begin{array}{c}\text { Farm-level agricultural operations including } \\
\text { storage. handling and transport of agricultural } \\
\text { products }\end{array}$ & NA & NA \\
\hline L_AgriOther & $3 \mathrm{Dd}$ & $\begin{array}{l}\text { Off-farm storage. handling and transport of } \\
\text { bulk agricultural products }\end{array}$ & NA & NA \\
\hline L_AgriOther & 3De & Cultivated crops & NA & NA \\
\hline L_AgriOther & 3Df & Use of pesticides & NA & NA \\
\hline L_AgriOther & $3 \mathrm{~F}$ & Field burning of agricultural residues & 0.02 & 0.02 \\
\hline L_AgriOther & $3 \mathrm{I}$ & Agriculture other (please specify in the IIR) & NO & $\mathrm{NO}$ \\
\hline \multicolumn{3}{|c|}{ Other Agricultural sector $\mathrm{NH}_{3}$ emission } & 274.27 & 287.91 \\
\hline \multicolumn{3}{|c|}{ National total $\mathrm{NH}_{3}$ emission } & 294.43 & 307.52 \\
\hline \multicolumn{3}{|c|}{ Other Agricultural sector/National total emission } & $93.15 \%$ & $93.62 \%$ \\
\hline
\end{tabular}

* Nomenclature for reporting.

In the area of agricultural production, including emission sites, three main groups of ammonia reduction can be distinguished-breeding (genetic), nutritional, and technological (environmental). Thanks to the progress in breeding, more and more knowledge about the characteristics of plants and animals can be obtained. This knowledge is also useful in the context of climate change challenges. Research in this area is constantly being carried out, including the field of biotechnology. The volume of ammonia emissions from livestock buildings depend on the animal husbandry system and the type of inventory. As numerous studies indicate, a very wide spectrum of reduction activities can be found in animal nutrition $[44,45]$. The composition of the food dose strongly influences the amount of ammonia emissions [46]. Feed additives, including those containing amino acids, reduce emissions. According to the research of Radcliffe et al. [47], if the amount of CP (crude protein) in the diet is reduced by using synthetic AA (amino acids), pigs will release much less nitrogen. From a technological point of view, modern means of production (e.g., feed additives in the form of probiotics, enzymes, acidifiers, and tannins; adding chemical and biotechnological preparations to litter and liquid manure) are important, as well as appropriate pro-ecological agri-environmental practices (optimal, in accordance with good practices, use of mineral and organic fertilizers, proper storage of fertilizers, etc.). Traditional, anaerobic 
manure storage is an inefficient method of managing these materials, often leading to a negative impact on the environment as a result of gaseous emissions. A very important technical aspect limiting the ammonia emission is also adequate ventilation of buildings and rooms where animals are kept [48,49]. The most important challenge is to introduce production methods and techniques that will help reduce the ammonia emission. The results of research in this field in Polish agriculture (nutritional and environmental elements) have been presented below.

\section{Results and Discussion}

The answers to the research questions were helpful in achieving the aim of the paper (Table 1). The results for the tested sample are presented below, broken down into farmers engaged in plant production $(n=1034)$ and livestock production $(n=520)$. Figures 2 and 3 present the results of analyses regarding the actions taken by the respondents to reduce ammonia emissions during agricultural production.

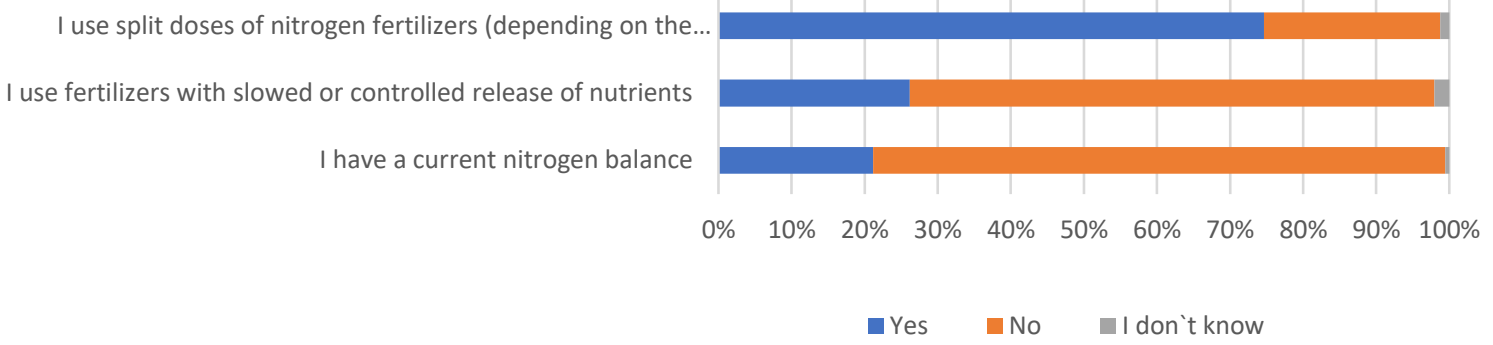

Figure 2. Declarations of respondents engaged in plant production on the methods of reducing ammonia emissions. Source: own study based on questionnaire surveys $(n=1034)$

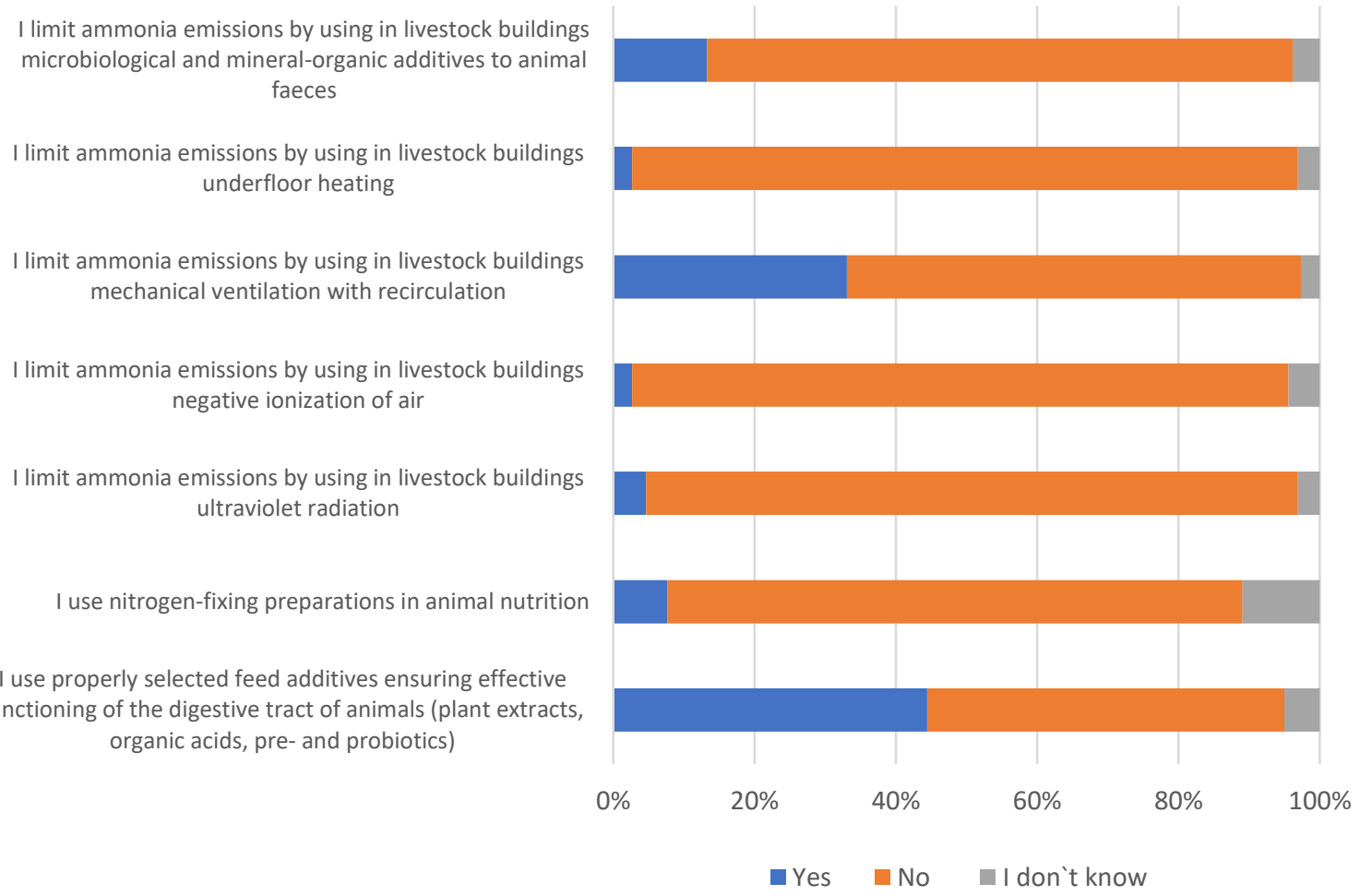

Figure 3. Declarations of respondents engaged in livestock production on the methods of reducing ammonia emissions. Source: own study based on questionnaire surveys $(n=520)$. 
As the analyses show, in the field of plant production, the most frequently undertaken action was the division of doses of nitrogen fertilizers ( $772 \mathrm{farms}$, i.e., $74.7 \%$ of the total number of respondents). Much less popular activities are the use of fertilizers with slow or controlled release of nutrients and the analyses of the nitrogen balance within the farm. On the other hand, in the field of livestock production, the most popular measure aimed at limiting ammonia emissions was the use of feed additives (231 farms out of a total of 520 , i.e., $44 \%$ of the surveyed livestock farmers).

Correspondence analysis was used for in-depth analysis of the input data. One of the most popular responses of the respondents from each category (i.e., in the field of plant and animal production) were selected for detailed analysis.

The first of the carried out analyses consisted in determining the coexistence between the declarations of agricultural producers related to the division of nitrogen fertilizer doses during the growing season with the variables characterizing the surveyed farmers and the attributes of their farms. Correspondence analyses of variables were performed on the basis of Burt's matrix. The values of the $\chi^{2}$ statistics and the $\varphi^{2}$ mean square multi-division for the data included in the above matrices are presented in Table 5.

Table 5. Statistics values $\chi^{2}$, critical values $\chi^{2}{ }_{\alpha=0.01}^{*}$ (in parentheses) and mean square contingency $\varphi^{2}$ for the following features: split doses of nitrogen fertilizers, arable land area, economics size of agriculture holding, and district.

\begin{tabular}{cccccc}
\hline$\chi^{2}$ & Arable Land Area & $\begin{array}{c}\text { Economic Size of } \\
\text { Agricultural Holding }\end{array}$ & District & Age & Education Level \\
\hline$\varphi^{\mathbf{2}}$ & $\mathbf{c}^{* *}=\mathbf{5}$ & $\mathbf{c}^{* *}=\mathbf{6}$ & $\mathbf{c}^{* *}=\mathbf{6}$ & $\mathbf{c}^{* *}=\mathbf{5}$ & $\mathbf{c}^{* *}=\mathbf{4}$ \\
\hline Split doses & 69.94997 & 119.64513 & 71.06556 & 7.46578 & 32.03019 \\
$\mathrm{r}^{* *}=3$ & $(20.0902)$ & $(23.2093)$ & $(23.2093)$ & $(20.0902)$ & $(16.8119)$ \\
& 0.06765 & 0.11571 & 0.06873 & 0.00722 & 0.030977 \\
\hline
\end{tabular}

${ }^{*}$ critical values $\chi^{2} \alpha=0.01$ read from the tables for $(\mathrm{r}-1) \times(\mathrm{c}-1)$ degrees of freedom. ${ }^{* *}$ number of rows and columns of the variables analyzed. Source: own study based on questionnaire surveys $(n=1034)$.

The verification of empirical values of $\chi^{2}$ leads to the conclusion that the hypothesis of the independence of features should be rejected for four pairs of features: dose division-arable land area; dose division-economic size of the farm, dose division-district, dose division-level of education. Definitely the highest relationship $\left(\varphi^{2}\right)$ was found between the variables for the pair of traits: dose division-economic size of a farm. A graphic presentation of the correspondence analysis results is shown in Figure 4.

The conducted analyses show that positive declarations about the division of fertilizer doses (E1) coexisted with categories S3 and W3. On the other hand, the lack of division of fertilizer doses or the lack of knowledge on this subject (E2 and E3) coexisted with categories S1 and U1. Thus, it can be concluded that the use of variable doses of nitrogen fertilizers, corresponding to the current requirements of arable crops, is popular on larger farms, where the owners have higher education than professional.

Another analysis was carried out in the field of animal production activities. In order to check whether there are dependencies between the analyzed features (the use of feed additives and the features of farmers and farms), the test of independence of nominal features was used based on the $\chi^{2}$ statistics (at the significance level $\alpha=0.01$ ). On the basis of the value of the $\chi^{2}$ statistics, the strength of the dependence of the variables was also determined, using the $\varphi^{2}$ mean square multi-division index (Table 6). 

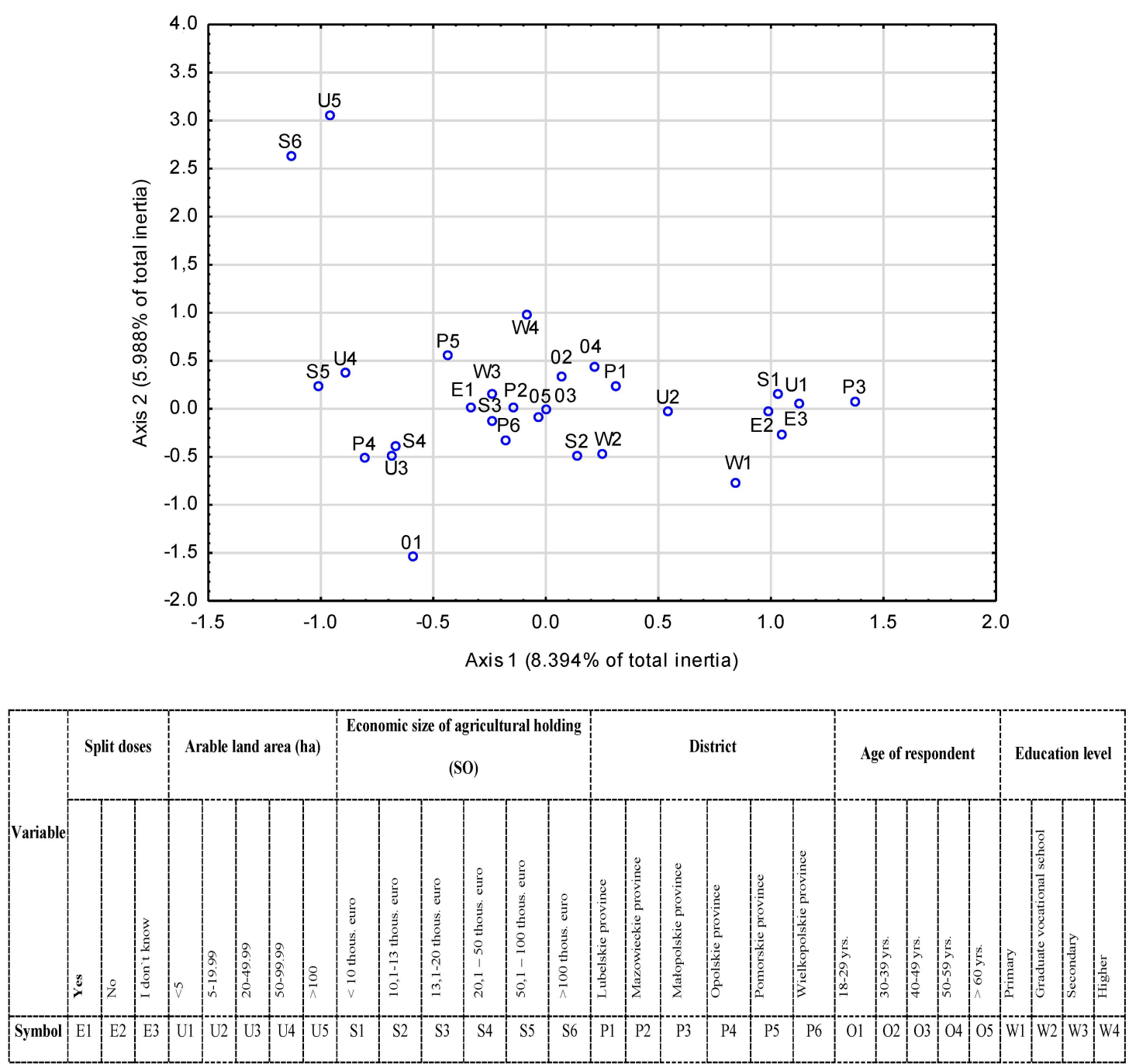

Figure 4. Graphical presentation of the results of the correspondence analysis between the declarations of sharing nitrogen fertilizer doses with the researched characteristics of farmers and farms. Source: own study based on questionnaire surveys $(n=1034)$.

Table 6. Statistics values $\chi^{2}$, critical values $\chi^{2} \alpha=0.01 *$ (in parentheses) and mean square contingency $\varphi^{2}$ for the following features: use feed additives, arable land area, economics size of agriculture holding, and district.

\begin{tabular}{cccccc}
\hline$\chi^{2}$ & Arable Land Area & $\begin{array}{c}\text { Economic Size of } \\
\text { Agricultural Holding }\end{array}$ & District & Age & Education Level \\
\hline $\boldsymbol{\varphi}^{\mathbf{2}}$ & $\mathbf{c}^{* *}=\mathbf{5}$ & $\mathbf{c}^{* *}=\mathbf{6}$ & $\mathbf{c}^{* *}=\mathbf{6}$ & $\mathbf{c}^{* *}=\mathbf{5}$ & $\mathbf{c}^{* *}=\mathbf{4}$ \\
\hline Use feed & 21.14259 & 37.75926 & 37.55571 & 8.41090 & 17.282774 \\
additives & $(20.0902)$ & $(23.2093)$ & $(23.2093)$ & $(20.0902)$ & $(16.8119)$ \\
$\mathrm{r}^{* *}=3$ & 0.040659 & 0.072614 & 0.072223 & 0.016175 & 0.033236 \\
\hline
\end{tabular}

* Critical values $\chi^{2} \alpha=0.01$ read from the tables for $(\mathrm{r}-1) \times(\mathrm{c}-1)$ degrees of freedom. ${ }^{* *}$ number of rows and columns of the variables analyzed. Source: own study based on questionnaire surveys $(n=520)$.

The critical values $\chi^{2}$ read from the distribution tables, with the significance level $\alpha=0.01$, for four pairs of features are smaller than the calculated $\chi^{2}$ statistics. This means that the hypothesis about the independence of the examined features should be rejected for pairs of variables: use of feed additives-size of the farm area; use of feed additives-economic size of the farm; use of feed 
additives-district; use of feed additives-education. The value of the $\varphi^{2}$ mean square multi-division, determining the strength of these relationships, indicates that the use of feed additives is most strongly determined by the economic size of a farm and the location of the farm (district). It should also be stated that the use of such additives does not depend on the age of the agricultural producer (similarly to the previous analysis, Table 5). Figure 5 shows a graphical presentation of the correspondence analysis results for these variables.
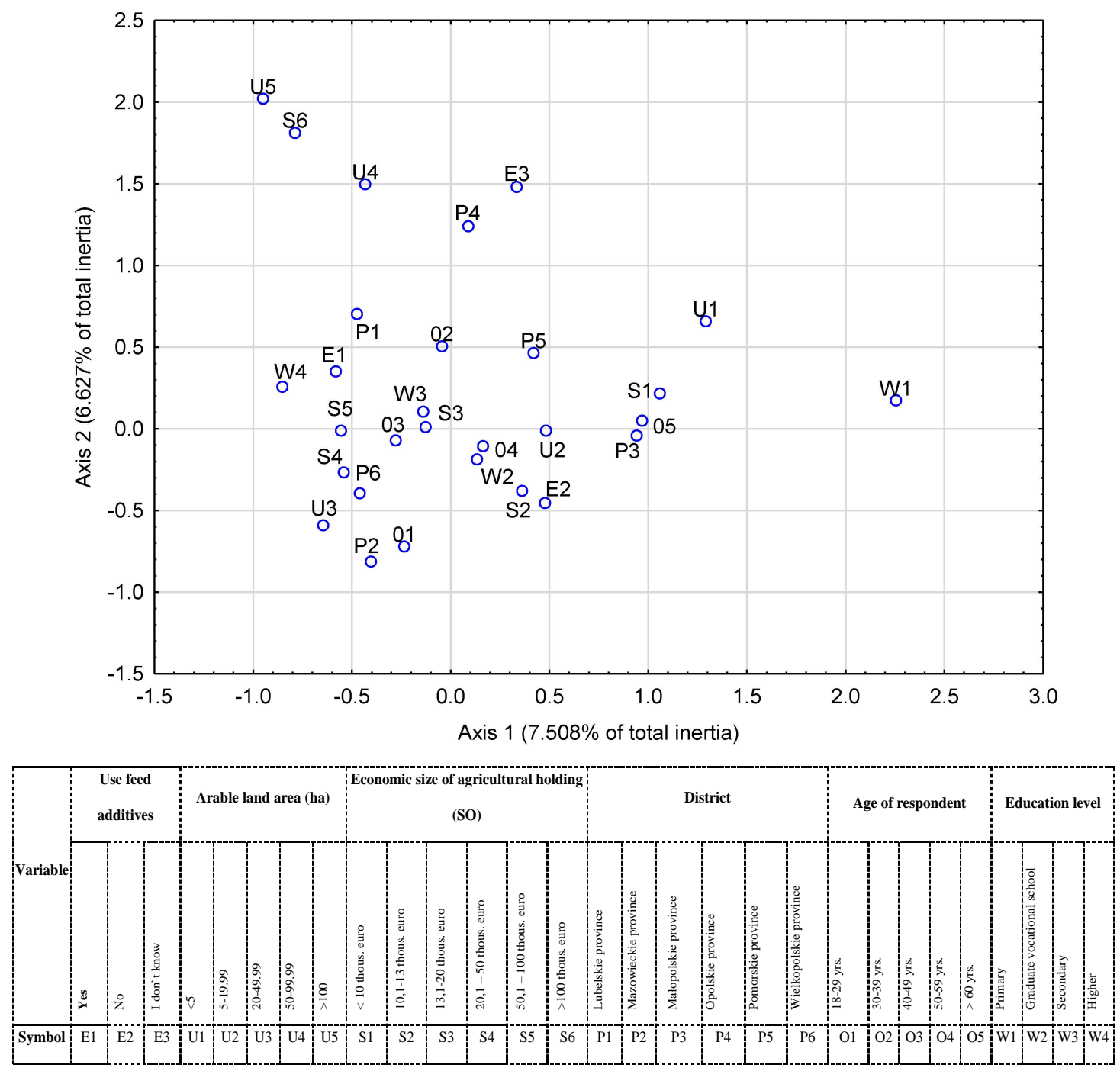

Figure 5. Graphical presentation of the results of the correspondence analysis between the declarations of using appropriately selected feed additives with the tested characteristics of farmers and farms. Source: own study based on questionnaire surveys $(n=520)$.

The results of the presentation of the correspondence analysis on the basis of Burt's matrix showed that there is a coexistence among the studied variables. Agricultural producers who declared the use of appropriate feed additives (E1) were characterized by higher education (W4) and a relatively high economic size of farms (S4 and S5). They were relatively young people (O2, O3). In turn, people not using such supplements (E2) are mainly people with vocational education (W2), rearing on a relatively small scale (U2, S2).

The issue of ammonia emissions from agricultural activities is one of the main challenges in Poland in the area of environmental protection. Ammonia is characterized by a high acidifying and eutrophicizing potential, hence the monitoring of ammonia emissions plays an important role in the 
international environmental policy. Poland has been committed to reducing ammonia emissions by $1 \%$ each year from 2020 to 2029. Compared to 2005, the overall scope for reducing emissions should be $17 \%$. This requires urgent changes in agricultural practices, the implementation of low-carbon fertilizer application and storage techniques, and animal housing and feeding systems.

Therefore, the methods and tools for reducing ammonia emissions have recently acquired particular importance. The studies by Jarosz and Faber [50] recommended the possibilities of reducing ammonia emissions. According to the authors, in the perspective of 2030, quick incorporation of natural fertilizers may have the greatest impact on reducing the total ammonia emissions in Poland. The action consisting in replacing urea with ammonium nitrate is also characterized by a great potential; moreover, spray-free application of slurry (with simultaneous incorporation of manure) is also important. Temperature is a parameter influencing the emission of gases from the slurry. At the same time, manure cooling systems during storage can be used [51,52]. Bieńkowski et al. [53] see the possibilities of reducing ammonia emissions in Poland also in the changes in manure storage and use on farms. An important issue concerns the infrastructure in utility rooms [54]. The implementation of solutions from other countries in the Baltic Sea region, e.g., from Denmark, may turn out to be significant in the subject matter in study. In this country, the slurry acidification method has been widely used since 2010 [55]. The use of the slurry acidification system technology enables the reduction of ammonia emissions both in livestock buildings and in tanks or directly in the field [56]. The literature on the subject emphasizes the need to develop methods for the inventory and forecasting of ammonia emissions in Poland [57].

\section{Summary}

Agricultural activity is not neutral for the natural environment, and in the course of agricultural production, harmful substances polluting soil, water and air are generated and accumulated. Excessive concentration of various types of pollution caused by agricultural activities has a negative impact on the natural environment, inhibits sustainable development, and worsens the quality of life. Maintaining a high level of productivity in Polish agriculture generates a serious burden for the natural environment, including the emission of ammonia. This applies to both the production and use of natural fertilizers (ammonia emission, especially during storage, and application of natural fertilizers), and the used animal husbandry systems. Due to the scale of animal production in Poland, especially poultry and pigs, an important way to reduce ammonia emissions from agriculture is to modify the applied methods of animal production (proper storage of slurry, poultry manure, etc.). In particular, the possibilities of effective management of poultry manure are crucial in the studied subject (use of manure for energy purposes as a substrate for biogas production; possibilities of processing chicken manure into biochar). Based on the analysis of the literature on the subject and the results of own research, it is possible to put forward a thesis that the technical, potential possibilities of reducing ammonia emissions in Polish agriculture are significant.

According to the presented research, low-emission practices aimed at reducing ammonia emissions from agricultural sources are not used on a large scale in Poland. There is relatively little interest of farmers in the use of innovative mineral fertilizers (e.g., urea with a urease inhibitor and nitrification; fertilizers with a controlled release of ingredients). On the other hand, in the field of animal production, the use of modern ventilation and air purification systems is minimal. Similarly, nutritional factors that could modify the described processes in animal production were not often practiced by the surveyed farmers as a means of reducing ammonia emissions. Precise balancing and reduction of protein concentration in the feed is an important direction that requires greater interest in agricultural practice in Poland. The implementation of sustainable agricultural practices requires financial and organizational efforts from farms. It is necessary to implement using large scale low-emission techniques for spreading and storing fertilizers as well as modern systems of keeping and feeding animals. It is necessary to modify and create instruments supporting not only investments in the studied area, but also the development of farmers' knowledge and skills. 
Analyses based on a detailed, representative study on the basis of a multiple correspondence analysis show significant variability between farms. This approach allowed for a more detailed analysis of farmers' behavior, taking into consideration demographic and social characteristics (age, education, etc.) and attributes of farms (e.g., area size and economic size). In general, it can be concluded that preferences regarding specific factors very often corresponded to the area of agricultural land, the economic size of the farm, the location of the farm and the education of the farmer.

Apart from the analysis of the current state of affairs, the proposals and recommendations for further research and development of research methods, techniques, and tools useful for solving the particular research problem are also important. Environmental protection in agricultural production in Poland, especially in terms of ammonia emissions, should be permanently included in the group of factors determining the selection of methods and technologies used in agricultural production. In Poland, small farms are still dominant (the average size of a farm area in 2017 did not exceed 11 ha of UAA), keeping small herds of animals and using traditional systems of maintenance. Changes in the application technique of organic fertilizers are necessary. In the case of slurry, it is possible to perform fertilization and cultivation at the same time (slurry tanker aggregated with a tine or disc applicator). Moreover, acidification of the animal slurry has proven to be an effective solution to minimize $\mathrm{NH}_{3}$ emissions. Natural fertilizers can also be an important input for the production of agricultural biogas. In terms of urea fertilization (pre-sowing), it is necessary to immediately mix it with the soil. Urea with a urease inhibitor should be used. Not only technical measures are important, but above all, their skillful application. For intensive rearing of pigs, cattle and poultry, appropriate low carbon techniques to reduce ammonia emissions should be implemented. In the light of increasingly stringent environmental requirements, especially precision farming elements should gain in importance (constant monitoring of air emissions from each livestock building, precise application of fertilizers to the soil, etc.).

Funding: This study was conducted and financed in the framework of the research project "The state and prospects of the development of low-carbon agriculture in Poland and the behavior of agricultural producers", granted by the National Science Centre in Poland, program SONATA, grant No. 2016/21/D/HS4/00087.

Conflicts of Interest: The author declares no conflict of interest.

\section{References}

1. Fu, H.; Luo, Z.; Hu, S. A temporal-spatial analysis and future trends of ammonia emissions in China. Sci. Total Environ. 2020, 731, 138897. [CrossRef]

2. Guo, X.; Ye, Z.; Chen, D.; Wu, H.; Shen, Y.; Liu, J.; Cheng, S. Prediction and mitigation potential of anthropogenic ammonia emissions within the Beijing-Tianjin-Hebei region, China. Environ. Pollut. 2020, 259, 113863. [CrossRef] [PubMed]

3. UNECE. The 1999 Gothenburg Protocol to Abate Acidification Eutrophication and Ground-level Ozone (22 July 2014). 1999. Available online: http://www.unece.org/fileadmin/DAM/env/lrtap/full\%20text/1999\% 20Multi.E.Amended.2005.pdf (accessed on 28 August 2020).

4. Battye, W.; Aneja, V.P.; Roelle, P.A. Evaluation and improvement of ammonia emissions inventories. Atmos. Environ. 2003, 37, 3873-3883. [CrossRef]

5. Sommer, S.G.; Hutchings, N.J.; Webb, J. New emission factors for calculation of ammonia volatilization from European livestock manure management systems. Front. Sustain. Food Syst. 2019, 3, 101. [CrossRef]

6. Bai, Z.; Dong, Y.; Wang, Z.; Zhu, T. Emission of ammonia from indoor concrete wall and assessment of human exposure. Environ. Int. 2006, 32, 303-311. [CrossRef] [PubMed]

7. Naseem, S.; King, A.J. Ammonia production in poultry houses can affect health of humans, birds, and the environment-Techniques for its reduction during poultry production. Environ. Sci. Pollut. Res. 2018, 25, 15269-15293. [CrossRef] [PubMed]

8. Wu, Y.; Gu, B.; Erisman, J.W.; Reis, S.; Fang, Y.; Lu, X.; Zhang, X. PM2.5 pollution is substantially affected by ammonia emissions in China. Environ. Pollut. 2016, 218, 86-94. [CrossRef] 
9. Giannakis, E.; Kushta, J.; Bruggeman, A.; Lelieveld, J. Costs and benefits of agricultural ammonia emission abatement options for compliance with European air quality regulations. Environ. Sci. Eur. 2019, $31,93$. [CrossRef]

10. Wielgosiński, G.; Czerwińska, J. Smog Episodes in Poland. Atmosphere 2020, 11, 277. [CrossRef]

11. Sutton, M.A.; Dragosits, U.; Tang, Y.S.; Fowler, D. Ammonia emissions from non-agricultural sources in the UK. Atmos. Environ. 2000, 34, 855-869. [CrossRef]

12. Sapek, A. Ammonia Emissions from Non-Agricultural Sources. Polish J. Environ. Stud. 2013, 22, 63-70.

13. Wu, C.; Wang, G.; Li, J.; Li, J.; Cao, C.; Ge, S.; Xie, Y.; Chen, J.; Liu, S.; Du, W.; et al. Non-agricultural sources dominate the atmospheric NH3 in Xi'an, a megacity in the semi-arid region of China. Sci. Total Environ. 2020, 722, 137756. [CrossRef] [PubMed]

14. Insausti, M.; Timmis, R.; Kinnersley, R.; Rufino, M.C. Advances in sensing ammonia from agricultural sources. Sci. Total Environ. 2020, 706, 135124. [CrossRef] [PubMed]

15. Aneja, V.P.; Nelson, D.R.; Roelle, P.A.; Walker, J.T.; Battye, W. Agricultural ammonia emissions and ammonium concentrations associated with aerosols and precipitation in the southeast United States. J. Geophys. Res. Atmos. 2003, 108. [CrossRef]

16. Hristov, A.N.; Hanigan, M.; Cole, A.; Todd, R.; McAllister, T.A.; Ndegwa, P.M.; Rotz, A. Ammonia emissions from dairy farms and beef feedlots. Can. J. Anim. Sci. 2011, 91, 1-35. [CrossRef]

17. Warner, J.X.; Dickerson, R.R.; Wei, Z.; Strow, L.L.; Wang, Y.; Liang, Q. Increased atmospheric ammonia over the world's major agricultural areas detected from space. Geophys. Res. Lett. 2017, 44, 2875-2884. [CrossRef]

18. Sun, K.; Tao, L.; Miller, D.J.; Pan, D.; Golston, L.M.; Zondlo, M.A.; Griffin, R.J.; Wallace, H.W.; Leong, Y.J.; Yang, M.M.; et al. Vehicle emissions as an important urban ammonia source in the United States and China. Environ. Sci. Technol. 2017, 51, 2472-2481. [CrossRef]

19. Castesana, P.S.; Dawidowski, L.E.; Finster, L.; Gómez, D.R.; Taboada, M.A. Ammonia emissions from the agriculture sector in Argentina; 2000-2012. Atmos. Environ. 2018, 178, 293-304. [CrossRef]

20. Huang, X.; Song, Y.; Li, M.; Li, J.; Huo, Q.; Cai, X.; Zhu, T.; Hu, M.; Zhang, H. A high-resolution ammonia emission inventory in China. Glob. Biogeochem. Cycles 2012, 26. [CrossRef]

21. Lam, S.K.; Suter, H.; Bai, M.; Walker, C.; Mosier, A.R.; van Grinsven, H.; Chen, D. Decreasing ammonia loss from an Australian pasture with the use of enhanced efficiency fertilizers. Agric. Ecosyst. Environ. 2019, 283, 106553. [CrossRef]

22. Zhang, N.; Bai, Z.; Winiwarter, W.; Ledgard, S.; Luo, J.; Liu, J.; Guo, Y.; Ma, L. Reducing Ammonia Emissions from Dairy Cattle Production via Cost-Effective Manure Management Techniques in China. Environ. Sci. Technol. 2019, 53, 11840-11848. [CrossRef] [PubMed]

23. Xu, R.; Tian, H.; Pan, S.; Prior, S.A.; Feng, Y.; Batchelor, W.D.; Chen, J.; Yang, J. Global ammonia emissions from synthetic nitrogen fertilizer applications in agricultural systems: Empirical and process-based estimates and uncertainty. Glob. Chang. Biol. 2019, 25, 314-326. [CrossRef] [PubMed]

24. Goebes, M.D.; Strader, R.; Davidson, C. An ammonia emission inventory for fertilizer application in the United States. Atmos. Environ. 2003, 37, 2539-2550. [CrossRef]

25. Sommer, S.G.; Hutchings, N.J. Ammonia emission from field applied manure and its reduction. Eur. J. Agron. 2001, 15, 1-15. [CrossRef]

26. Ammonia Emissions from Agriculture (Source: EEA). Available online: https://ec.europa.eu/eurostat/tgm/ table.do?tab=table\&init=1\&plugin=1\&language=en\&pcode=sdg_02_60 (accessed on 5 August 2020).

27. Dróżdż, D.; Wystalska, K.; Malińska, K.; Grosser, A.; Grobelak, A.; Kacprzak, M. Management of poultry manure in Poland-Current state and future perspectives. J. Environ. Manag. 2020, 264, 110327. [CrossRef]

28. Rzeźnik, W.; Mielcarek, P. Greenhouse Gases and Ammonia Emission Factors from Livestock Buildings for Pigs and Dairy Cows. Polish J. Environ. Stud. 2016, 25, 1813-1821. [CrossRef]

29. Faber, A.; Jarosz, Z.; Żyłowski, T. Weryfikacja możliwości redukcji emisji amoniaku dla różnych praktyk aplikacji gnojowicy w Polsce. Problemy Rolnictwa Światowego 2019, 19, 31-40. (In Polish) [CrossRef]

30. Erisman, J.W.; Schaap, M. The need for ammonia abatement with respect to secondary PM reductions in Europe. Environ. Pollut. 2003, 129, 159-163. [CrossRef]

31. Anderson, N.; Strader, R.; Davidson, C. Airborne reduced nitrogen: Ammonia emissions from agriculture and other sources. Environ. Int. 2003, 29, 277-286. [CrossRef] 
32. Dzikuć, M.; Kułyk, P.; Dzikuć, M.; Urban, S.; Piwowar, A. Outline of Ecological and Economic Problems Associated with the Low Emission Reductions in the Lubuskie Voivodeship (Poland). Polish J. Environ. Stud. 2019, 28, 1-8.

33. Olszowski, T. Influence of Individual Household Heating on PM2.5 Concentration in a Rural Settlement. Atmosphere 2019, 10, 782. [CrossRef]

34. Łowicki, D. Landscape pattern as an indicator of urban air pollution of particulate matter in Poland. Ecol. Indic. 2019, 97, 17-24. [CrossRef]

35. Piwowar, A. Agricultural biogas-An important element in the circular and low-carbon development in Poland. Energies 2020, 13, 1733. [CrossRef]

36. Piwowar, A. Low carbon agriculture in Poland-Theoretical and practical challenges. Polish J. Environ. Stud. 2019, 28, 2785-2792. [CrossRef]

37. The Role of Agriculture in Polish Economy. Available online: https://www.igipz.pan.pl/tl_files/igipz/ ZGWiRL/ARP/01.Znaczenie\%20rolnictwa\%20w\%20gospodarce\%20Polski.pdf (accessed on 2 August 2020).

38. Hoffman, D.L.; De Leeuw, J. Interpreting multiple correspondence analysis as a multidimensional scaling method. Mark. Lett. 1992, 3, 259-272. [CrossRef]

39. Cavallo, E.; Ferrari, E.; Bollani, L.; Coccia, M. Attitudes and behaviour of adopters of technological innovations in agricultural tractors: A case study in Italian agricultural system. Agric. Syst. 2014, 130, 44-54. [CrossRef]

40. Ter Braak, C.J. The analysis of vegetation-environment relationships by canonical correspondence analysis. Vegetatio 1987, 69, 69-77. [CrossRef]

41. Brunette, M.; Bourke, R.; Hanewinkel, M.; Yousefpour, R. Adaptation to climate change in forestry: A multiple correspondence analysis (MCA). Forests 2018, 9, 20. [CrossRef]

42. Zhao, Z.; Jiang, Y.; Xia, L.; Mi, T.; Yan, W.; Gao, Y.; Jiang, X.; Fawundu, E.; Hussain, J. Application of canonical correspondence analysis to determine the ecological contribution of phytoplankton to PCBs bioaccumulation in Qinhuai River, Nanjing, China. Environ. Sci. Pollut. Res. 2014, 21, 3091-3103. [CrossRef]

43. Materiały do pobrania w kategorii: Krajowa inwentaryzacja emisjiDrukuj. Available online: https://www. kobize.pl/pl/fileCategory/id/16/krajowa-inwentaryzacja-emisji (accessed on 2 August 2020).

44. Canh, T.T.; Aarnink, A.J.A.; Schutte, J.B.; Sutton, A.; Langhout, D.J.; Verstegen, M.W.A. Dietary protein affects nitrogen excretion and ammonia emission from slurry of growing-finishing pigs. Livest. Prod. Sci. 1998, 56, 181-191. [CrossRef]

45. Wang, H.; Long, W.; Chadwick, D.; Velthof, G.L.; Oenema, O.; Ma, W.; Wang, J.; Wei, Q.; Hou, T.; Zhang, F. Can dietary manipulations improve the productivity of pigs with lower environmental and economic cost? A global meta-analysis. Agric. Ecosyst. Environ. 2020, 289, 106748. [CrossRef]

46. Liu, S.; Ni, J.Q.; Radcliffe, J.S.; Vonderohe, C.E. Mitigation of ammonia emissions from pig production using reduced dietary crude protein with amino acid supplementation. Bioresour. Technol. 2017, 233, 200-208. [CrossRef] [PubMed]

47. Radcliffe, S.; Richert, B.; Sholly, D.; Foster, K.; Hollas, B.; Lim, T.; Ni, J.; Heber, A.; Sutton, A. Diet modification to reduce odors, gas emissions and nutrient excretions from swine operations. In Proceedings of the Mitigating Air Emissions from Animal Feeding Operations, Des Moines, Iowa, 19-20 May 2005; pp. 114-119.

48. Dach, J. Polish experience with ammonia emission abatement for straw-based manure. In Emissions from European Agriculture; Wageningen Academic Publishers: Wageningen, The Netherlands, 2005; pp. 295-303.

49. Dach, J.; Niżewski, P.; Czekała, J.; Zbytek, Z. Comparison of ammonia emission from composted swine farmyard manure and composted sewage sludge. J. Res. Appl. Agric. Eng. 2008, 53, 58-64.

50. Jarosz, Z.; Faber, A. Possibilities of reducing ammonia emissions from agriculture-Scenario for 2030. Ann. PAAAE 2020, 22, 41-48. [CrossRef]

51. Rzeźnik, W. Ograniczanie emisji zanieczyszczeń gazowych z tuczarni poprzez zastosowanie instalacji do odzysku ciepła. Inżynieria Rol. 2013, 3, 331-339. (In Polish)

52. Misselbrook, T.; Hunt, J.; Perazzolo, F.; Provolo, G. Greenhouse gas and ammonia emissions from slurry storage: Impacts of temperature and potential mitigation through covering (pig slurry) or acidification (cattle slurry). J. Environ. Qual. 2016, 45, 1520-1530. [CrossRef]

53. Bieńkowski, J.; Jankowski, J.; Holka, M. Emisje amoniaku w rolnictwie zagrożeniem dla środowiska. Aura 2018, 3, 3-5. (In Polish)

54. Chiumenti, A.; da Borso, F.; Pezzuolo, A.; Sartori, L.; Chiumenti, R. Ammonia and greenhouse gas emissions from slatted dairy barn floors cleaned by robotic scrapers. Res. Agric. Eng. 2018, 64, 26-33. 
55. Fangueiro, D.; Hjorth, M.; Gioelli, F. Acidification of animal slurry-A review. J. Environ. Manag. 2015, 149, 46-56. [CrossRef]

56. Mazur, K.; Barwicki, J.; Borek, K.; Wardal, W.J. Procesy chemiczne w glebie przy stosowaniu gnojowicy zakwaszonej kwasem siarkowym w uprawach polowych. Przemyst Chem. 2019, 98, 424-428. (In Polish) [CrossRef]

57. Wlazło, Ł.; Nowakowicz-Dębek, B.; Kułażyński, M.; Wnuk, W.; Ossowski, M. Modelowanie rozprzestrzeniania się amoniaku w powietrzu atmosferycznym wokół fermy drobiu. Przemyst Chem. 2018, 97, 645-647. (In Polish) [CrossRef]

Publisher's Note: MDPI stays neutral with regard to jurisdictional claims in published maps and institutional affiliations.

(C) 2020 by the author. Licensee MDPI, Basel, Switzerland. This article is an open access article distributed under the terms and conditions of the Creative Commons Attribution (CC BY) license (http://creativecommons.org/licenses/by/4.0/). 